Michael Kofman

\title{
A TALE OF TWO CAMPAIGNS: U.S. AND RUSSIAN MILITARY OPERATIONS IN SYRIA
}

DOI: 10.20542/2307-1494-2017-1-163-170

Keywords: Syria, United States, Russia, ISIS, “Jabhat al-Nusra”, Iraq, Turkey, the Kurds, Iran

Abstract: $\quad$ Even in the absence of direct military and counterterrorist cooperation on Syria, both the United States and Russia have made progress on the battlefield without hampering the efforts of the other. On the one hand, the two countries have successfully prosecuted two parallel military campaigns in pursuit of their respective interests. De facto status of cobelligerents has forced Washington and Moscow to set up deconfliction mechanisms and restore limited military to military contacts under the Trump administration. On the other hand, it is increasingly difficult to keep the two campaigns separate, with more U.S. and Turkish forces operating in close proximity to those of Syria and Iran. The United States and Russia have been insufficiently empowered to control regional allies and impose their politics on the conflict. Crucial questions remain on Syria's post-conflict settlement, the political future of the Assad regime, and what happens after the defeat of ISIS. Syrian state weakness, sectarian divide, and foreign interference provide both fuel and opportunity for the conflict to continue. Meanwhile, none of the external powers have a vision for how to stabilize this country or even extricate themselves from the battlefield.

Ключевые Сирия, США, Россия, ИГИЛ, «Джабхат ан-Нусра», Ирак, Турция, курды, Иран слова:

Аннотация: Даже в отсутствие прямого военного и контртеррористического сотрудничества по Сирии, США и Россия добились прогресса на поле боя, при этом не препятствуя усилиям друг друга. С одной стороны, обе страны успешно ведут две параллельные военные кампании, преследуя свои интересы. Фактический статус совоюющих сторон заставил Вашингтон и Москву наладить механизм урегулирования возможных инцидентов, а при администрации Трампа - восстановить ограниченные контакты по военной линии. С другой стороны, соблюдать разграничение между двумя кампаниями все труднее в условиях, когда американские и турецкие войска действуют в непосредственной близости от сирийских правительственных сил и иранских фоормирований. И у США, и у России недостаточно рычагов для того, чтобы контролировать своих союзников в регионе и диктовать свою политическую линию. Критическое значение сохраняют вопросы постконфликтного урегулирования в Сирии и политического будущего режима Асада, а также проблемы безопасности и борьбы с терроризмом после разгрома ИГИЛ. Слабость сирийского государства, конфессиональные противоречия и внешнее вмешательство сохраняют условия для продолжения конфликта. В то же время ни у одной из внешних держав нет видения того, как стабилизировать страну или даже найти для себя стратегию выхода из боевых действий. 


\section{Introduction}

At present, the United States and Russia find themselves engaged in complementary, and increasingly overlapping, campaigns in Syria and Northern Iraq. The leadership of both countries describes these expeditionary operations as counterterrorism or counterinsurgency efforts, though they differ broadly on the political character of the intended targets. Although unacknowledged, the two countries have upheld a tacit if uncomfortable division of labor for much of the conflict period since $2014 .{ }^{1}$ A series of fortuitous events together with deliberate foreign policy choices, and their attendant consequences, resulted into Washington and Moscow employing military power within the same theater of operations. As Russia and the United States make steady progress on the battlefield, their respective leaderships must grapple with a creeping convergence of military efforts on the Syrian map. As battle lines narrow and buffers disappear, there is increasing friction among coalition allies, and the operating environment is fraught with risk of incident.

Paradoxically, both Moscow and Washington had sought ardently to stay out of Syria and avoid entrapment in a Middle Eastern conflict that had no discernible resolution. Yet national security imperatives first drew the United States back to support Iraqi forces in the summer of 2014, and subsequently Russia to save the Assad regime from collapse, in September of 2015. While successful military to military cooperation has eluded the two countries, or perhaps more accurately, has been eschewed by one or the other at varying times, both nonetheless have made progress on the battlefield without hampering the efforts of the other. A de facto status of cobelligerents exists between Washington and Moscow, forcing them to maintain deconfliction mechanisms out of prudence and in recent months even restore military to military contacts under the Trump administration.

In Northern Iraq and Eastern Syria, the United States has targeted the Islamic State (also known as ISIS or ISIL) and splinter terrorist groups loosely affiliated with al-Qaeda, first with airpower, then special forces, and increasingly a larger conventional military presence in 2016. The U.S.-led air and ground effort has been steadily clawing away at ISIS territory since 2015, with military defeat for the organization largely a matter of time at this juncture. Meanwhile, Russia began its intervention in Syria by deploying fixed wing and rotary wing aviation to "Hmeimim" airbase in 2015, subsequently expanding the footprint of its operation to include special operations forces, or SSO (abbreviation in Russian), armor, and artillery. That campaign was initially focused on preserving the Syrian regime, but substantially degraded "Jabhat alNusra" and engaged ISIS in select battles.

This article explores the military and political dimensions of American and Russian military counterterrorism efforts in the region, reflecting on the history of their respective campaigns, and offering perspectives for the future, though cognizant that the story of both war efforts is far from over. 


\section{The U.S. campaign against ISIS in 2014-2015}

The United States' decision to return to Iraq, after disengaging in 2010, was less a matter of choice and more a decision borne of exigent circumstances. As the proxy conflict in Syria simmered unabated, in 2014 roughly 6000 ISIS militants invaded across the border into Northern Iraq. The militants quickly captured Mosul, then Baiji and Tikrit fell as the Iraqi army dissipated. Surprised by the ease of their gains, ISIS quickly moved to proclaim an "Islamic Caliphate" in both Syria and Northern Iraq. ${ }^{2}$ After some political prevarication seeking to displace Iraq's divisive leader, Nouri al-Maliki, the United States responded by announcing an air campaign to support the Iraqi military. At this stage Russia was only incidentally helpful to bolstering the Iraqi effort, having sold Iraq "Mi28N" attack helicopters as part of a USD 4.2 billion deal signed in $2012 .{ }^{3}$ In the summer of 2014, Russia rushed "Su-25" ground attack aircraft, together with military advisers, to help the Iraqi military in their fight. ${ }^{4}$

By October 2014, the U.S. operation received the title "Inherent Resolve", expanding it to a broader coalition effort that included both Western allies and several Arab countries. Given Iraq's shortages of manpower, Shia militias played a decisive role in stemming the tide of the ISIS advance during 2014-2015, while elsewhere the United States leveraged Kurdish allies and their Peshmerga fighters. American special forces worked behind ISIS lines seeking out high value targets. The initial objective was first to contain ISIS gains, with minimal U.S. involvement. There were also humanitarian crises to contend with, helping Yazidis surrounded by ISIS fighters, and a later siege in Kobane of isolated Kurds.

Coalition airstrikes intensified in 2015 , under an operation newly named as "Tidal Wave II", intended to be a homage to the historic bombing campaign against Germany's oil production in Romania during World War II. Early hopes that ISIS gains could be rolled back with limited U.S. support were dashed when Ramadi fell, though this would prove to be ISIS' last major gain in Iraq. In 2015, it became clear that it would take Iraqi and Kurdish forces much longer to be in position to retake Mosul and eventually siege Raqqa, ISIS' stronghold in Syria. Indeed, it was only in late 2016 that the battle for the outskirts of Mosul began. The U.S. approach was deliberately slow, seeking to manage the ISIS problem without being forced to return a large military presence to Iraq. Washington's strategy was principally an economy of effort, leveraging whatever local forces were available and accepting a slow slog rather as the price of not returning to Iraq.

The approach demonstrated success, but political costs mounted. ISIS metastasized and began to make appearances in other parts of the Middle East and North Africa, in particular Libya. While Iraqi forces, together with Shia militias and coalition air support would ultimately retake Ramadi, their progress was fitful, and some of the practices unsavory. The vision for Iraq's army was predicated on training six new brigades worth of dependable forces, which could be counted upon to take the offensive. In Syria, the U.S. supported its traditional Kurdish allies in the region, over 
Turkish objections, a decision which would have important consequences in 2016-2017. Despite best efforts to make the fight a regional effort with Arab ownership of what was a problem borne of the Iraqi and Syrian conflict, non-Western coalition allies began to disappear. UAE and Saudi Arabia were more interested in pursuing their war in Yemen. Characteristically, the U.S.-led effort steadily became a U.S. owned effort, requiring gradual increases in military presence: the very thing the Obama administration sought to avoid.

\section{Russia's Intervention in Syria since 2015}

Despite frequent portrayals of Russia's intervention in Syria as a geopolitical gambit, designed to break out of political isolation by the United States on the international arena, in reality all these dimensions were secondary or tertiary to practical considerations that forced Moscow's hand in September 2015. In the spring of that year, the Syrian regime suffered several defeats, despite Iranian and Hezbollah support. In the northwest regions of the country regime forces were being driven back by "Jabhat alNusra", an al-Qaeda affiliate that had assembled several groups into the "Army of Conquest". ISIS was not only advancing in Iraq, but was expanding west, taking the historic city of Palmyra from Assad's forces. By April of 2015, the situation for the Syrian regime appeared dire. Russian arms and Shia militias alone would not suffice to sustain the Syrian regime's fight against a coalition of extremist and opposition fighters backed by Syria's neighbors.

In the summer of 2015, the head of Iran's Quds Force, Qassem Soleimani, made several trips to Moscow, along with senior Syrian officials, to coordinate a military intervention. ${ }^{5}$ By September 2015, Russian multirole fighters and tactical bombers began deploying to "Hmeimim" airbase in Latakia province to launch an air campaign in support of Syrian forces and what would become Russia's first true expeditionary operation in decades. Moscow quickly cobbled together a coalition with Iran and Syria, entering into special arrangements with Israel and Iraq. Cooperation with Turkey remained elusive, as Ankara was still fixated on regime change in Syria, but on the whole the political environment in the region proved largely accommodating to Moscow's intervention.

Russia's military strategy was in some ways similar to the U.S. approach, but less deliberate and more emergent. Initially Russian forces sought to stem the advance of antiregime forces, destroy captured equipment, and soften up the opposition. Then together with Iranian troops, Hezbollah, and the Syrian army or what was left of it, it began to launch offensives. These proved costly, but sustained stress on the opposition started to take effect. The initial goal of the Russian-led coalition was to retake the initiative against the "Army of Conquest", capture important roads, infrastructure, and reconnect with isolated or surrounded Syrian bases. The hope was that success would beget success, Iranian and Syrian forces probed for weaknesses and exploited breakthroughs in the opposition's line. 
The arrival of Russian forces introduced a new dynamic to the conflict, forcing a conversation on deconfliction arrangements between American and Russian officials. In truth, this situation was unprecedented in the post-Cold War period. The United States had not only enjoyed a monopoly on use of force in the region for much of the 1990s and 2000s, but air dominance was almost assumed in any U.S.-led efforts. Two military powers, operating in the same air space without coordination, created risk and uncertainty for both sides. That concern, which remains ever-present today, proved justified when Turkey shot down a Russian "Su-24" in November 2015, spawning a bilateral political crisis. The incident was arguably a game of brinksmanship gone wrong, as Russia had intentionally violated Turkish airspace before, but did not properly calculate Ankara's willingness to use force in order to make a point.

Although diplomatic channels proved fruitful in restarting a dialogue on political settlement in Syria, namely the Geneva process pressed forward by Secretary of State John Kerry and Foreign Minister Sergei Lavrov, the two coalitions never agreed on a common approach to fighting terrorism. At the root of the problem were politics and a path dependency of previously declared policy. The U.S. ardently stuck to the delineation of a legitimate moderate opposition, which Russia never truly acknowledged, seeing all anti-Assad forces as de facto varying shades of extremists. Thus, the Russian operation was focused, first and foremost, on the forces which posed a threat to the regime, independent of their character. Although claiming to fight ISIS, Russia's air force largely left ISIS alone to what was proving to be a complementary campaign in Syria being waged by the United States.

Moscow was equally frustrated by the fact that the United States was less interested in targeting "Jabhat al-Nusra", a powerful jihadist group with clear ideological affinity for al-Qaeda. From Russia's perspective, the United States coalition was less concerned with ISIS gains against Syrian forces, seeing them as a problem in Iraq, but a useful element in collapsing the Syrian regime. Turkey too was unabashedly more comfortable with ISIS across its borders compared to the existential threat posed by the Kurds. At the outset of the operation, speaking at the UN, Vladimir Putin had presented the Russian position: "We think it is an enormous mistake to refuse to cooperate with the Syrian government and its armed forces who are valiantly fighting terrorism face to face. We should finally acknowledge that no one but President Assad's armed forces and Kurdish militias are truly fighting the Islamic State and other terrorist organizations in Syria". ${ }^{6}$ This painted the conflict zone with a broad brush: effectively Russia saw anyone other than the Kurds as fair game for its campaign.

Despite lasting political differences, Russia and the United States reached a memorandum of understanding to establish in-flight protocols for deconflicting their operations by October 2015..$^{7}$ By December, the Russian campaign began to show results, and in January and February 2016 it was evident that the Syrian opposition and extremist groups were in retreat. In March, Russia turned its sights on ISIS-held Palmyra, retaking the historic city, while its Syrian and Iranian allies began to position themselves for an offensive on Aleppo, a bastion of the opposition. 
Palmyra exposed differences in operational objectives within the Russian-led coalition: Moscow was more interested in consolidating gains than pitched battles for Syrian cities, but its allies were adamant in pursuing victory over opposition held Homs and Aleppo. This resulted in the first Russian declaration of withdrawal from Syria, a political and military deleveraging intended to normalize the military presence and settle in for the long haul. Like the United States, Moscow came to the realization that gains would prove slow and fitful and sought a smaller footprint to avoid being dragged in further by the machinations of local allies.

\section{The politics of counterterrorism}

The respective campaigns made substantial progress in 2016. With Russian support, Syrian and Iranian forces would ultimately seize Aleppo, consolidate control of Homs, and eat away at ISIS territory. Although counterattacks resulted in another battle for Palmyra, the opposition and other groups fighting the Assad regime were on an unalterable declining trajectory. Iraqi and Kurdish forces too gained ground, retaking many of the cities initially ceded to ISIS and besieging Mosul by early 2017. The two campaigns increasingly encroached on each other's operating space, with Russia and the United States becoming de facto cobelligerents. Like air squeezed in a balloon, ISIS was trapped between the expanding territorial control of Syrian forces to the West, Kurds to the North, and the Iraqi army to the South.

Political convergence would prove elusive, despite the increasingly compressed battlefield. While early Russian efforts to bring the U.S. onboard with its operations in September 2015 did not work out, in July 2016 Washington proposed a joint integration group to work together. However, one of the chief conditions of the deal was to ground the Syrian air force and find a means of saving Aleppo by imposing a nationwide ceasefire. At the same time Russia steered negotiations to make the United States acknowledge that no true firebreak or separation existed between "moderate" and extremist forces, i. e. the two were fully comingled on the battlefield and thus fair game for bombing.

Given that recapturing Aleppo was a core objective for Syria and Iran, Russia was simply not in a position to deliver on a ceasefire, and the deal collapsed spectacularly in September 2016. Mutual recriminations followed, and the failed peace effort exposed that both countries were insufficiently empowered to control regional allies and impose their politics on the conflict. Although Russia portrayed itself as a powerbroker and lead negotiator on behalf of Syria, the role was more aspirational than actual.

As Russia grappled with the differing machinations of its allies, the U.S. too proved unable to reconcile the internal contradictions within its coalition. These cleavages are significant for both countries, since competing imperatives would not only prove divisive, but substantially complicate combat operations. Driving ISIS back with Kurdish help was a constant point of friction between the United States and Turkey, in contradiction with the desire to maintain Turkish support. Ankara saw the Kurds as an existential threat to 
its territorial integrity, much more so than ISIS. Eventually, as Kurdish territory expanded, Turkey sought rapprochement with Moscow in 2016, looking to overcome the break in relations caused by the "Su-24" incident. This policy realignment rebalanced Turkey's position, with Ankara stepping back from a quest for regime change in Syria, instead seeking to secure its interests through cooperation with Russia as much as the United States.

\section{Looking into an uncertain future}

In 2016 the Turkish army intervened in Syria, though chiefly to prevent the Kurds from establishing a contiguous territory. By 2017, the respective coalitions met around the Syrian town of Manbij. The U.S. forces, the Turkish army, and the Russian military are now operating in increasing proximity of each other, as ISIS territory melts away. The Trump administration's recent decision to arm the YPG Kurdish militia in Syria will also have ramifications for Washington's relations with Ankara. Despite what seem to have been best efforts to avoid military cooperation, the two countries have in fact managed to successfully prosecute two military campaigns in pursuit of their respective interests. However, it will prove increasingly difficult to keep them separate, with more U.S. and Turkish forces operating in close proximity to those of Syria and Iran.

The recent U.S. cruise missile strikes ordered against "al-Shayrat" airbase in retaliation for Assad's use of chemical weapons also indicate an increasing tolerance for risk in Washington. Though the Russian forces were given due warning and presence at the airbase was minimal, if at all, the strike will have an impact on Moscow's decision making. Despite early indications that the Trump administration is interested and open to seeing Russia as a partner in its counterterrorism operations, following the strike statements indicate that no formal coordination is likely to emerge (at least not in the near future). As such, the risk on the battlefield continues to compound, and decisions actors make directly impact their neighbors in the theater of operations.

More profound questions also remain on Syria's postconflict settlement, the political future of the Assad regime, and what happens after ISIS. While Russia has few answers for how Syria should come together assuming its coalition is successful, the United States continues to be vexed by the question of how to prevent the "next ISIS" from spawning in the region. Syrian state weakness, sectarian divide, and foreign intervention provide both fuel and opportunity for the conflict to continue, and none of the external powers have answers for how to stabilize this country in the long term or even extricate themselves from the battlefield. 


\section{ENDNOTES}

${ }^{1}$ Landis J., Simon S. Assad has it his way // Foreign Affairs. 19 January 2016.

URL: <https://www.foreignaffairs.com/articles/syria/2016-01-19/assad-has-it-his-way>.

${ }^{2}$ Chulov M. ISIS insurgents seize control of Iraqi city of Mosul // The Guardian. 10 June 2014.

URL: <https://www.theguardian.com/world/2014/jun/10/iraq-sunni-insurgents-islamic-militantsseizecontrol-mosul>.

3 Russia delivers more attack helicopters to Iraq for fight against ISIS // The Moscow Times. 2 February 2015. URL: <https://themoscowtimes.com/articles/russia-delivers-more-attackhelicoptersto-iraq-for-fight-against-is-43451>.

4 Weir F. Russia to the rescue in Iraq? Moscow delivers jet fighters to Baghdad // The Christian Science Monitor. 30 June 2014. URL: <http://www.csmonitor.com/World/Europe/2014/0630/Russiato -the-rescue-in-Iraq-Moscow-delivers-jet-fighters-to-Baghdad>. As many as 21 "Su-25s" were operated by the Iraqi air force in 2016.

5 Iran Quds chief visited Russia despite U.N. travel ban: Iran official // Reuters. 7 August 2015. URL: <http://www.reuters.com/article/us-russia-iran-soleimani-idUSKCN0QC1KM20150807>.

6 Read Putin's U.N. General Assembly speech // The Washington Post. 28 September 2015. URL: <https://www.washingtonpost.com/news/worldviews/wp/2015/09/28/readputins-u-n-generalassembly-speech/>.

7 Lubold G. U.S., Russia reach agreement on Syrian flights // The Wall Street Journal. 20 October 2015. URL: <http://www.wsj.com/articles/u-s-russia-reach-agreement-on-syrian-flights-

1445371698>. 